\title{
Potential Masking of the Baltic Grey Seal Vocalisations by Underwater Shipping Noise in the Lithuanian Area of the Baltic Sea
}

\author{
Donatas Bagočius \\ Marine Science and Technology Centre, Klaipéda University, Klaipéda, Lithuania
}

Corresponding author:

D. Bagočius, Marine Science and Technology Centre, Klaipéda University, H. Manto St 84, Klaipéda, Lithuania

E-mail:donatas.bagocius@jmtc.ku.lt

\begin{abstract}
Acoustical surveys were completed in the Lithuanian Sea Museum and the Lithuanian area of the Baltic Sea during the period of 2012-2013. Underwater vocalisations of the Baltic grey seals were recorded and collated with underwater shipping noise recorded in the shallow area of the Lithuanian area of the Baltic Sea with the aim to evaluate possible masking of social vocalisations of animals. The following paper focuses not on the complex biomedical auditory or brain stem response research, but on the acoustical measurements and evaluation of possible masking of social vocalisations of grey seals by shipping noise. The results of the survey show masking potential of grey seal communication calls at significant distance in the presence of local shipping noise where the detection distance of calls between conspecifics can be significantly reduced.
\end{abstract}

Keywords: acoustics, underwater noise, grey seal vocalisations, masking potential.

\section{Introduction}

As a general statement, all studied marine mammals can produce sounds in various important contexts. They use sound in social interactions as well as to forage, to orient, and to respond to predators (Southall et al., 2007). The social vocalisations of grey seals (Halichoerus grypus) in the air form an important part of recognition behaviour between mother and offspring, among territorial males and other species recognition. The pups of greys seals have individualistic calls, which are used for individual recognition of pups by females like the males of pinniped species use a complex repertoire for threat calls (Insley et al., 2003; Coffey, 1977).

Grey seals being amphibious animals vocalise in the air and underwater. According to Schusterman (1978), it appears likely that underwater calls of seals serve the same socially communicative functions as in air calls. Grey seals have about seven types of underwater calls during the breeding season (Asselin et al., 1993), which usually have a low frequency component ranging between $0.1-0.3 \mathrm{kHz}$, some of them with the upsweeps up to $4.7 \mathrm{kHz}$ (Whitlow and Hastings, 2008).

It is hypothesised that vocalisations of mammals coincide with the range of hearing, and these assumptions are based on an adaptive argument that vocal energy should be selected to fall within the range of hearing for maximum efficiency of communication. However, several lines of evidence suggest that other adaptive pressures may shape the vocal range, and the number of selective forces can drive the development of an emphasis on low frequency energy in vocalisations not matched by the shape of the auditory threshold function (Southall et al., 2007). The process of auditory masking occurs when the perception of a given signal is negatively influenced by the presence of another sound (Reichmuth, 2012). Noise can mask signals such as communication sounds, echolocation, predator and prey sounds, and environmental sounds where masking by itself depends on the spectral and temporal characteristics of signal and noise. At a low signal to noise ratio (SNR), a signal might just be 
audible. A higher signal to noise ratio is needed for signal recognition and discrimination and an even higher signal to noise ratio for comfortable communication in a presence of noise (Erbe, 2012). The latter paper subsequently presents the research results having an emphasis on masking potential of the social underwater vocalisations of the Baltic grey seal (Halichoerus grypus fabricius).

\section{Methods}

The vocal cues of the animals were recorded at the Lithuanian Sea Museum during the period of April-May 2012 and March of the year 2013. In the period of April 2012, vocalisations of 4 individuals of different age - two males and two females - were recorded in the semicircle elongated pool having the volume of $242 \mathrm{~m}^{3}$ and the depth of $2.3 \mathrm{~m}$. In the period of May 2012, vocalisations of 3 male pups were recorded in the small square pool having the volume of $35 \mathrm{~m}^{3}$ and the depth of $2.1 \mathrm{~m}$. In the period of March 2013, vocalisations of 5 individuals of different age - three males and two females - were recorded during their mating season in the semicircle elongated pool with parameters mentioned above. During the recordings, a hydrophone was submersed to $1-1.5 \mathrm{~m}$ depth in the pools.

For the purpose of analysis and comparison, a shipping noise was recorded in the Lithuanian area of the Baltic Sea on July 2013. The noise of the standard ro-ro passenger ship having the gross tonnage of 25,518 ktonnes and draft of $6.4 \mathrm{~m}$ passing Lithuanian territorial waters at the speed of 20 knots was recorded in the distance of $\sim 200 \mathrm{~m}$ from the ship at the sea depth of $43.3 \mathrm{~m}$ (hydrophone submersed to $20 \mathrm{~m}$ depth). For acoustical surveys, the cable hydrophone Aquarianaudio $H 2 A$ (effective frequency response $0.01-100 \mathrm{kHz}$ ) with the digital audio recorder (DAR) ZOOM H1 (effective frequency range $0.02-48 \mathrm{kHz}$ ) were used. Recordings were made using 16-bit accuracy, build in preamplifier with gain of $0-39 \mathrm{~dB}$ and sampling frequency of $44.1-48 \mathrm{kHz}$. Audio files were processed with the signal processing software Raven pro 1.4 using a Discrete Fourier transform using Hanning windowing with a 3-dB bandwidth filter of $124 \mathrm{~Hz}$ (spectrograms) and $248 \mathrm{~Hz}$ (spectrums) and time grid overlap of $50 \%$. After the completion of audio and visual analysis of vocalisation spectrograms, 4 main groups of calls were determined. Successfully, all the vocalisations were correlated using the batch spectrogram correlator (see Charif et al., 2010) to test correlations of calls against determined groups.

\section{$3 \quad$ Results and discussion}

During the spectral and audio analysis of seal vocalisations, 4 main groups of animal calls either of pups or mature animals during the regular and mating seasons were found. From the audio data $n=203$ calls of the animals were picked out, and 9 calls were rejected as unsuitable for the analysis. The main calls were: roars, rups, growls and click trains. During audio analysis, it was found that roars comprised $22.16 \%$, rups $-45.88 \%$, growls $-2.09 \%$ and click trains - 29.87\%. During the automated batch correlation analysis, $n=3,184$ correlations were completed, and roars comprised $-54.68 \%$, rups $7.39 \%$, growls $-14.29 \%$ and click trains $-23.65 \%$. Part of correlations $(9.36 \%)$ had a correlation coefficient $<0.7$ showing moderate correlation. However, the dominating calls were rups and click trains (determined during the audio analysis). Groups of calls consisted of calls having different duration and tonal components, some of the calls were a combination of two or more types of calls. The example of the spectrogram view of vocalisations groups is shown in Figure 1.

Viewed grey seal vocalisations lied within the frequency range of $0.1-5 \mathrm{kHz}$ having the centre frequencies of $0.25-1.3 \mathrm{kHz}$. Main parameters of these vocalisations are shown in Table 1. Vocalisations had average sound power of 52-71 dB re $1 \mu \mathrm{Pa}^{2} / \mathrm{Hz}$. Exclusively rups transmitted by the oldest male seal reached up the maximum sound power of $103 \mathrm{~dB}$ during the mating season, perhaps having the meaning of female attraction. Thereby animal vocalisations are part of communication system which is directly related to animal hearing. Hearing organs of pinnipeds are homologous to the hearing of terrestrial mammals, in other words, as stated by researchers Mohl and Ronald 1975, the hearing organs of pinnipeds function in the same manner for airborne sounds as of terrestrial mammals. Therefore, it is reasonable to suppose that pinnipeds like humans, probably hear sounds underwater through the bone conduction, having directional and frequency discrimination capabilities (Whitlow and Hastings, 2008). In natural shallow Baltic Sea environment, vocalisations of seals by conspecifics would be heard at relatively short distance as animal vocalisations have relatively low sound power of 52$71 \mathrm{~dB}$. The reasons for this are properties of natural shallow environment, where the decay of sound power constitutes at least $\sim 30 \mathrm{~dB}$ at first 100 metres (considering spherical-cylindrical sound transmission loss). 


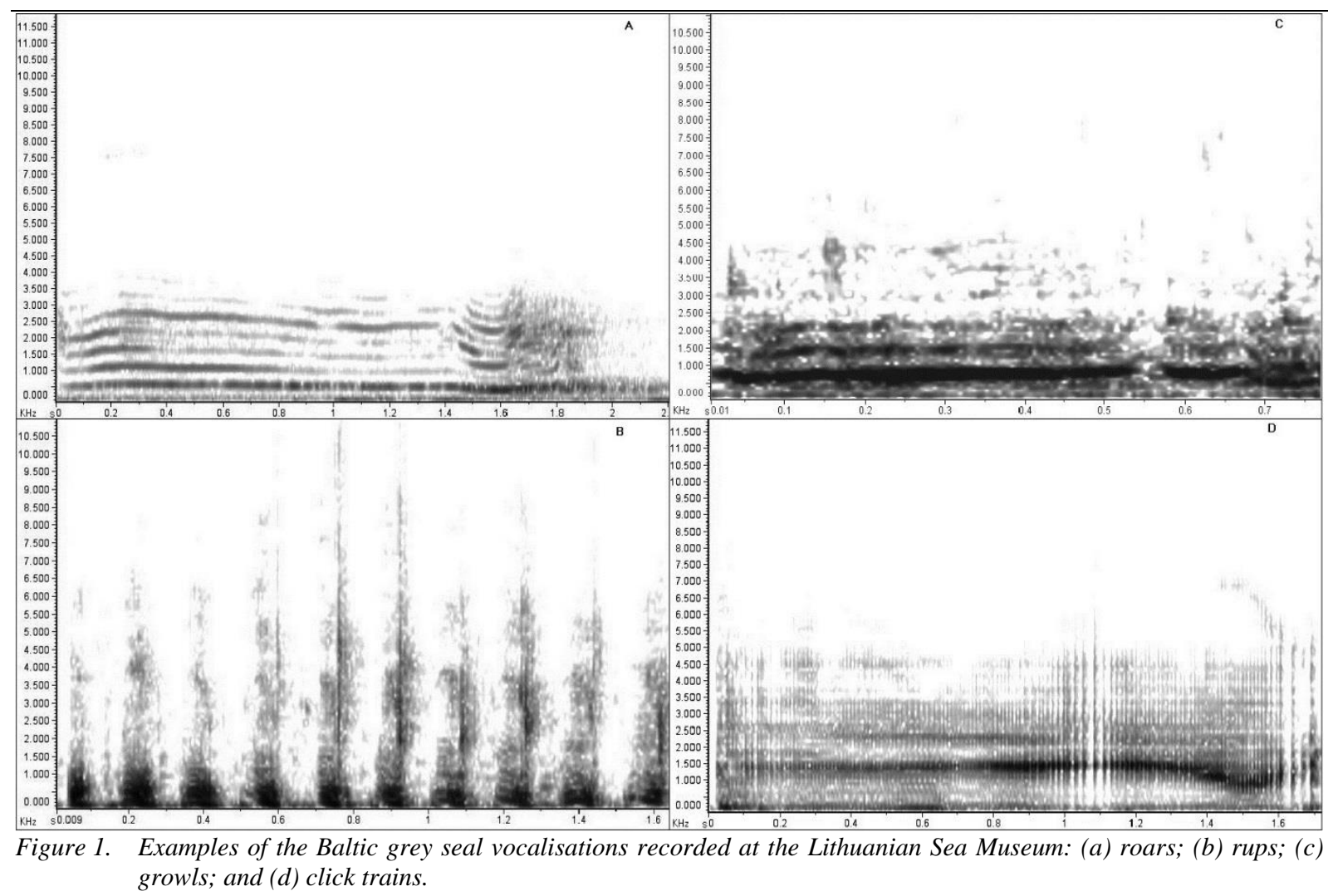

Table 1. Acoustical parameters of the viewed grey seal vocalisations.

\begin{tabular}{||c|c|c|c|c||}
\hline \hline Call type & Average sound power & Maximum sound power & Centre frequency & Signal duration (90\%) \\
\hline Roar & $52 \mathrm{~dB}$ & $81 \mathrm{~dB}$ & $468 \mathrm{~Hz}$ & $1.7 \mathrm{~s}$ \\
\hline Rups & $71 \mathrm{~dB}$ & $103 \mathrm{~dB}$ & $258 \mathrm{~Hz}$ & $1.4 \mathrm{~s}$ \\
\hline Growl & $68 \mathrm{~dB}$ & $92 \mathrm{~dB}$ & $690 \mathrm{~Hz}$ & $0.5 \mathrm{~s}$ \\
\hline Click trains & $60 \mathrm{~dB}$ & $87 \mathrm{~dB}$ & $1,312 \mathrm{~Hz}$ & $1.4 \mathrm{~s}$ \\
\hline
\end{tabular}

Thus vocalisations of pinnipeds can be easily masked by natural background or man-made noise. In the Lithuanian area of the Baltic Sea the main source of anthropogenic underwater noise is shipping, having the pressure of average 6-7 $\mathrm{K}$ passing vessels yearly (Helcom maps, 2014). The types of vessels that render the biggest contribution to the shipping traffic in the Baltic Sea are: general cargo vessels, containerships; product, oil, chemical tankers; bulk carriers; ferry/ro-ro and ro-ro vessels. These categories make up approximately $90 \%$ of the sailed miles in the Baltic Sea. Weighted forecast for the cargo traffic growth (ship passages) in the Baltic Sea region is estimated at $\sim 0.9 \%$ yearly until 2020 . Forecast for the vessel size growth is estimated at $0.2-2.4 \%$ yearly depending on the vessel size (except for chemical tankers and general cargo ships) until 2020 in the Danish waters (Brisk, 2012). Relying on the forecast data regarding shipping traffic increase during the period of 2010-2030 in the Lithuanian area of the Baltic Sea proposed by Polish scientists (Kowalczyk and Piotrowizc, 2012), the contribution of overall shipping noise during this period in Lithuanian waters can be roughly estimated. The prognosis of the vessel's total volume increase in Lithuanian waters constitutes 6.8 million tonnes until
2030. For noise forecast the following relation can be used (NRC, 2003):

Change in shipping noise $(\mathrm{dB})$

$$
=20 \log \frac{\text { final gross tonnage }}{\text { initial gross tonnage }}
$$

Total volume of vessels passing Lithuanian waters in 2010 constituted $37,929,200 \mathrm{t}$ and the prognosis for the year 2030 is approximately $44,718,069 \mathrm{t}$. Thus taking in consideration that Lithuanian waters have only few main shipping routes and using relation (1), a rough estimate of trend of total contribution of average shipping noise to Lithuanian waters is $1.43 \mathrm{~dB}$ until 2030. However, in shallow waters, local shipping noise dominates and the distant shipping noise is absent as deep favourable propagation paths travelled by distant shipping noise in deep waters are absent in shallow waters; in other words, the poor transmission in shallow waters screens out the noise of distant ships and allows locally generated wind noise to dominate the spectrum at all frequencies (Urick, 1984). The Baltic Sea has the mean depth of $54 \mathrm{~m}$ (Leparanta and Myrberg, 2009), whereas the Lithuanian area of the Baltic Sea is comparatively shallow (IOW, 2008). 


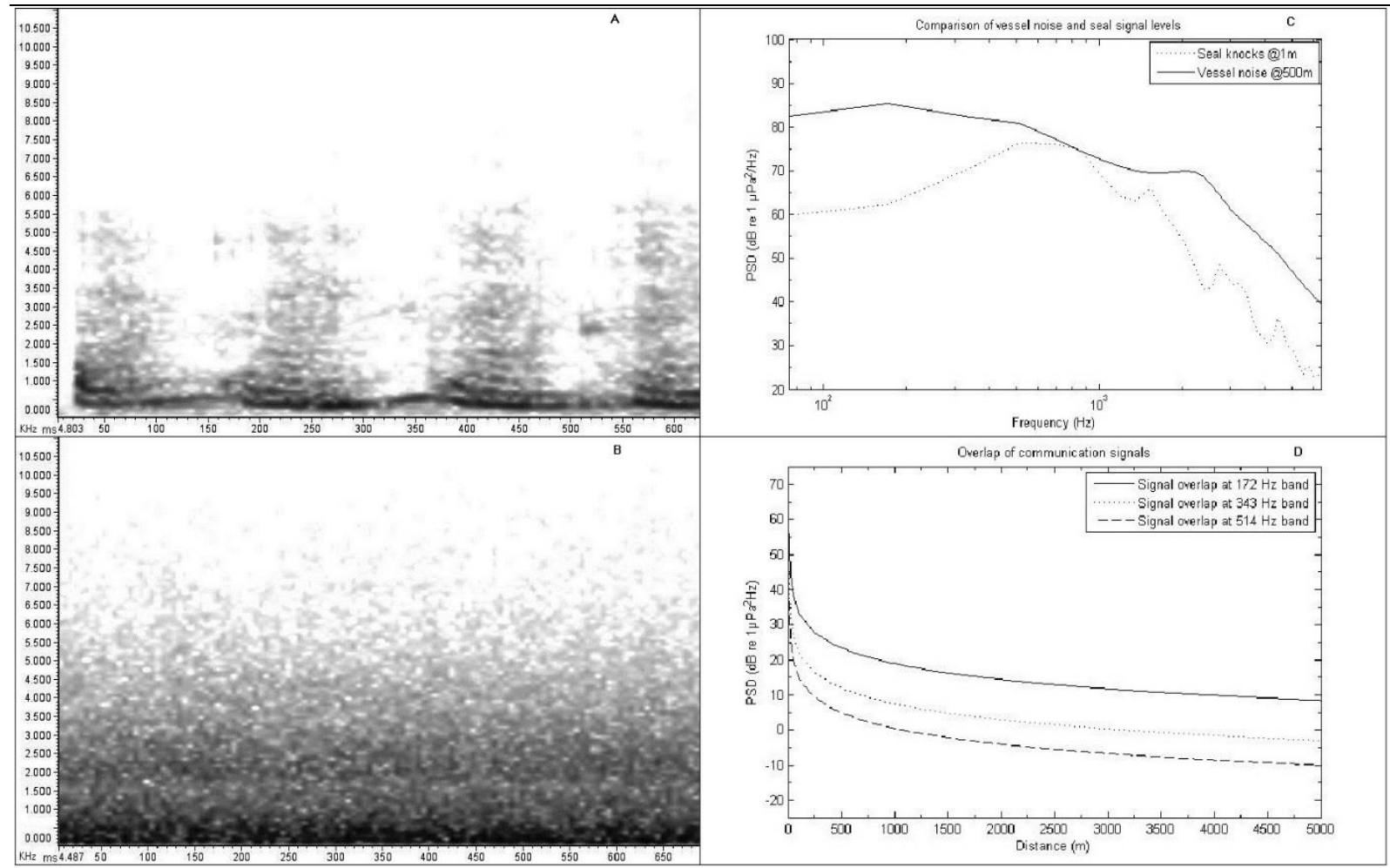

Figure 2. Comparison of the seal call and ship noise: (a) spectrogram of the grey seal rups; (b) ro-ro vessel noise spectrogram @200 m; (c) overlap of grey seal call with vessel noise (spectrum); (d) overlap of the grey seal call with vessel noise at separate low frequency bands due to distance.

The spectrograms of the local shipping noise of a standard ro-ro vessel passing the Lithuanian area of the Baltic Sea and the grey seal rups recorded during the mating season are compared in Figures $2 \mathrm{~A}$ and $2 \mathrm{~B}$, where a vessel noise constituted an average sound power level of $74 \mathrm{~dB}$ and a maximum sound power level of $92 \mathrm{~dB}$ at the distance of $200 \mathrm{~m}$. Vessel noise overlaps the seal communication signal throughout all frequency bands.

In Figure 2C, a comparison of the noise levels at wide frequency range (spectrums) shows complete overlap of the seal communication signal even at the distance of $500 \mathrm{~m}$ from the noise source, considering spherical-cylindrical noise propagation by the relation:

$$
T L=15 \log R
$$

where $T L$ is noise transmission loss, $R$ is distance from the noise source (Filatova and Fedutin, 2011).

The signal to noise ratio is an important issue whilst examining the masking potential of animal vocalisations. As the SNR has to be positive value and, moreover, has to have higher values for comfortable communication, the signal to noise ratio can be expressed as a simple relation:

$$
S L-N L \geq D T
$$

where $S L$ is signal level; $N L$ is noise level; $D T$ is detection threshold.

This equation is the foundation upon which all the versions of the sonar equations are based, and is simply a specialised statement of the law of the conservation of energy (FAS, 2013). By the relation the signal level or the animal call sound level has to be higher positive value compared with the vessel noise level due to detection or hearing threshold. If we assume that in the natural environment animals communicate being at a close distance from each other (i.e. audible distance between the two seals less than $10 \mathrm{~m}$, see Southall et al., 2000), a relation can be simply stated as: $N L-S L<0$, where the signal to noise ratio has to be a negative value for the call to be just audible (taking in consideration that animal calls have enough sound power to be heard by conspecifics).

Figure 2D shows an estimation of the grey seal call (series of rups) overlap with the vessel noise at three different low frequency bands. As shown in Figure 2D, the communication signal at low frequency band of $172 \mathrm{~Hz}$ can be overlapped by vessel noise at a distance of up to $5 \mathrm{~km}$, and the signal can be then masked at distances up to thousands metres at higher frequency bands. The estimation in Figure 2D, however, does not encompass the critical ratio $(\mathrm{CR})$, which by itself is a complex issue.

The critical ratio is the ratio which compares the level of a signal at the moment it is just detectable (the masked threshold) to the level of the background noise. For instance, if an animal can hear a particular signal over $70 \mathrm{~dB}$ of ambient noise when the signal reaches $90 \mathrm{~dB}$, then the critical ratio is $20 \mathrm{~dB}$. It should be noted that critical ratios are conserved for each frequency, regardless of increasing ambient levels. So if the ambient noise increased to $100 \mathrm{~dB}$, then the signal would have to be at least $120 \mathrm{~dB}$ 
before the animal could detect it. The value of the critical ratio has important ecological significance as high ambient levels could conceivably raise detection thresholds beyond the absolute acoustic energy emitted by many boats (Gerstein, 2014). Critical ratios of pinnipeds found to vary between $10-20 \mathrm{~dB}$ over frequency bands of $100-500 \mathrm{~Hz}$ (Southall et al., 2000). Thus while estimating masking potential it should be taken into consideration that the overlap of the signal should be supplemented with the critical ratio and the distance at which the animal call is overlapped by the man-made noise.

Equally it should be noted that the noise generated by the passing vessel has a certain directivity due to propellers noise and hull interaction. The result of this phenomenon makes higher noise levels at the stern and the sides of the vessel comparing with the noise at the bow of the vessel, where a vessel noise is accompanied with cavitating propeller blade noise (see Gerstein 2014, Arveson and Vendittis, 1999). Marine mammals also are able to adopt their hearing and signalling due to noise. Sounds with pulsed characteristics, harmonic elements, frequency modulation or amplitude modulation may require lower signal to noise ratios for detection, i.e. some mammal species respond to calls of conspecifics while signals played back with partial frequency component of the signal (Filatova and Fedutin, 2011). Mammals as other vertebrates can adjust their calls in response to disturbing noise where four main adjustment types are known; these include changes to the 1) amplitude of the signal, 2) frequency content of the signal, 3) temporal structure within the sound, and/or 4) the timing of sound production (Parks et al., 2012).

In other words, there is a variety of conditions where the detection of signals in noise can be improved by auditory or behavioural 'unmasking' processes. Spatial release from masking (SRM) occurs when the masking effects of collocated signals and maskers are reduced because the signals and maskers are spatially segregated and directional hearing is sufficient to support enhanced detection. The comodulation masking release (CMR) occurs when the energy in masking noise is coherently modulated in time across frequency regions rather than randomly modulated, as often found in real noise environments. The distinctiveness between mere detection of sounds in noise and discrimination, recognition, and, ultimately, effective communication also should be noted (Reichmuth, 2012). Critical ratios (CR) are available for pinnipeds but not exactly for grey seals, as the data about the grey seal hearing critical ratios are scarce in the present day. It should be considered as well that all recordings of the grey seal communication signals were made in reverberant pools having a different acoustical properties compared with the wild nature.

The issue by itself emphasises the importance of mitigation of noise impacts. In the present day there are known shipping noise mitigation measures, which can be implemented at organisational and technical level. At organisational level, measures such as ship speed reductions and routing area restrictions (in ecologically sensitive areas) could be taken. From the technological point of view the shipping noise can be reduced by changing the design of helix; modifying propulsion system; modifying hull configuration; using air injection systems (bubble shield in front of and around the propeller); modifying the vibration isolators; using additional acoustic insulation (engine room and auxiliary devices), external/internal coatings purposed for sound damping; reducing machinery source (Southall and Scholik-Schlomer, 2008, Erbe, 2012).

\section{Conclusions}

Shipping traffic in the Lithuanian area of the Baltic Sea is comparatively dense (6-7 K vessels yearly) and widespread. The numbers of vessel passages in the Baltics has a forecast of steady annual increase by $0.9 \%$; moreover, the sizes of vessels are said to be increasing. Thus, the total shipping noise budget also increases, where rough forecast shows a $1.43 \mathrm{~dB}$ increase of shipping noise in Lithuanian waters by 2030 . The shipping traffic generates local shipping noise which is audible for grey seals at the distances reaching thousands of metres measured from the noise source and depends on the vessel technical parameters, including the directivity of propeller generated noise. Shipping noise dominates at low frequency bands, though propagate throughout water column, and in the presence of communicating, grey seals have a potential to mask their calls at great distances. Thus vessel noise can reduce an audible distance between two communicating seals to a very short distance. Consequently, the adverse acoustical conditions make an acoustical communication of conspecifics uncomfortable or even impossible leading to ecological impacts on animal populations. Obtained results stimulate the discussion regarding the application of mitigation techniques, which are known to be organisational and technical. However, due to complex shipping traffic in the Baltic Sea region, these measures seem to be appropriate at regional level.

\section{Acknowledgements}

The author is grateful to senior biologist of the Lithuanian Sea Museum Mr Arūnas Grušas for giving an opportunity to complete acoustical recordings of animals' vocalisations.

\section{References}

Arveson, P.T. and Vendittis, D.J. (1999) Radiated noise characteristics of a modern cargo ship. J. Acoust. Soc. Am. 107(1): 118 - 129. doi: http://dx.doi.org/10.1121/ 1.428344

Asselin, S., Hammill, M.O., and Barette, C. (1993) Underwater vocalisations of ice breeding grey seals, Canadian Journal of Zoology 71(11): 2211 - 2219. 
[Cross reference: Whitlow, W.L.A., Hastings, C.M., (2008). Principles of marine bioacoustics. Springer Science+Business Media, LLC 2008, 679 pp.]. doi: http://dx.doi.org/10.1139/z93-310.

Baltic Sea Research Institute (IOW) (2008). Topographic map of the Baltic Sea. Available at: http://www.iowarnemuende.de/topography-of-the-baltic-sea.html (accessed 1/3/2014).

BRISK (2012). Project on sub-regional risk of spill of oil and hazardous substances in the Baltic Sea. Model report: Part 1 - Ship traffic. Admiral Danish Fleet HQ, National Operation, Maritime Environment. 34 pp.

Charif, R.A., Waack, A.M., Strickman, L.M. (2010). Raven Pro 1.4 User's Manual. Cornell Lab of Ornithology, Ithaca, NY, pp. 367. Available at: http://www.birds.cornell.edu/brp/raven/RavenDocument ation.html (accessed 1/3/2014).

Coffey, D.J. (1977). Dolphins, Whales and Porpoises. An Encyclopaedia of Sea Mammals, pp. 223. New York: Macmillan Publishing.

Erbe, C. (2012) Effects of underwater noise on mammals. In: Popper, A.N. and Hawkins, A. (Eds.) The Effects of Noise on Aquatic Life. Advances in Experimental Medicine and Biology 730: 17 - 22. Springer Science+Business Media, LLC 2012, pp. 695. doi: http://dx.doi.org/10.1007/978-1-4419-7311-5_3.

Federation of American Scientists (FAS) 2013. Principles of underwater sound. Chapter 8. Available at: https://www.fas.org/man/dod-101/navy/docs/fun/ part08.htm (accessed 1/3/2014).

Filatova, O.A. and Fedutin, I.D. (2011) Responses of Kamchatkan fish eating killer whales to playbacks of conspecific calls. Marine mammal science 27(2): 26-42. doi: http://dx.doi.org/10.1111/j.1748 7692.2010.00433.x

Gerstein, E. (2014) Manatees, Bioacoustics and Boats. American Scientist (Future article). Available at: http://www.americanscientist.org/issues/num2/2002/2/ manatees-bioacoustics-and-boats/1 (accessed 1/3/2014).

HELCOM MAPS (2014). Helcom AIS monthly shipping density 2011. Available at: http://maps.helcom.fi/ website/mapservice/index.html (accessed 1/5/2014).

Insley, S.J., Phillips, A.V., Charier, I. (2003) A review of social recognition in pinnipeds. Aquatic Mammals 29(2): 181-201. Available at: http://www.cb.upsud.fr/pdf/InsleyPhillipsCharrier_AquaticMammals_2 003.pdf (accessed 1/5/2014).

Kowalczyk, U. and Piotrowizc, J. (2012). Clean Baltic Sea shipping project - maritime trends and perspectives. Maritime Institute in Gdańsk. Midterm Conference Cleanship, Riga 19-20 Sept 2012.

Leparanta, M. and Myrberg, K. (2009) Physical oceanography of the Baltic Sea, pp. 320, Springer Berlin Heidelberg. doi: http://dx.doi.org/10.1007/978-3540-79703-6.

Mohl, B. and Ronald, K. (1975). The peripheral auditory system of the Harp seal Pagophohilus groenlandicus, (Erxleben 1777). Rapp. P.-V. Reun. Cons. Int. Explor. Mer. 169, 516 - 523 [Cross reference: Whitlow, W.L.A., Hastings, C.M., Principles of marine bioacoustics. Springer Science+Business Media, LLC 2008, pp. 679].

NRC (2003). Ocean noise and marine mammals. National Research Council, Committee on Potential Impacts of Ambient Noise in the Ocean on Marine Mammals, 204 pp.

Parks S.E., Johnson, P.M., Nowacek, D.P., Tyack, P. (2012). Changes in vocal behaviour of North Atlantic Right whales in increased noise. In: Popper, A.N. and Hawkins, A. (Eds.) The Effects of Noise on Aquatic Life.
Advances in Experimental Medicine and Biology 730: 23-27. Springer Science+Business Media, LLC 2012, pp. 695.

Reichmuth, C. (2012). Psychophysical Studies of Auditory Masking in Marine Mammals: Key Concepts and New Directions. In: Popper, A.N. and Hawkins, A. (Eds.) The Effects of Noise on Aquatic Life. Advances in Experimental Medicine and Biology 730, Springer Science+Business Media, LLC 2012, pp. 695.

Schusterman, R.J. (1978). Vocal communication in pinnipeds. In: Markowitz, H. and Stevns, V.J. (Eds.) Behaviour of captive wild animals (pp. 247 - 308). Chicago, USA: Nelson - Hall. [Cross reference: Whitlow, W.L.A., Hastings, C.M., Principles of marine bioacoustics. Springer Science+Business Media, LLC 2008, pp. 679].

Southall, B.L., Schusterman, R.J., Kastak, D. (2000) Masking in three pinnipeds: Underwater, low-frequency critical ratios. Acoustical Society of America 108(3):1322 - $1366 . \quad$ Available at: http://www.ncbi.nlm.nih.gov/pubmed/11008832 (accessed 1/5/2014).

Southall, B.L., Bowles, A.E., Ellison, W.T., Finneran, J.J., Gentry, R.L., Greene, C.R. Jr., Kastak, D., Ketten, D.R., Miller, J.H., Nachtigall, P.E., Richardson, W.J., Thomas, J.A., Tyack, P.L. (2007). Marine mammal noise exposure criteria: initial scientific recommendations. Aquatic Mammals 33(4): 411 - 414. Available at: http://sea-inc.net/assets/pdf/ mmnoise_aquaticmammals.pdf (accessed 1/5/2014).

Southall, B.L. and Scholik-Schlomer, A. (2008). Final report of the NOAA International Symposium "Potential Application of Vessel Quieting Technology on Large Commercial Vessels", Silver Spring, MD, U.S.A., 1 - 2 May 2007, pp. 47.

Urick, R.J. (1984). Ambient Noise in the Sea. Washington, D.C.: Undersea Warfare Technology Office, Naval Sea Systems Command.

Whitlow, W.L.A., and Hastings, C.M. (2008). Principles of marine bioacoustics, pp. 679. Springer. 


\title{
Pilkụjų Baltijos jūros ruonių vokalizacijos ir jų potencialus maskavimas povandeniniu laivybos triukšmu
}

\author{
Donatas Bagočius \\ Jüros mokslu ir technologijų centras, Klaipédos universitetas, Klaipėda, Lietuva
}

\begin{abstract}
Dauguma jūros žinduolių, ịskaitant pilkuosius Baltijos ruonius (Halichoerus grypus fabricius), naudoja balso vokalizacijas poravimosi metu priešingos lyties atstovams vilioti, nepageidaujamiems gyvūnams iš savo mègstamų teritorijų atgrasyti, o patelès naudoja vokalizacijas bendrauti su mažyliais. Manoma, jog ruonių povandeninès vokalizacijos ir vokalizacijos, naudojamos atmosferinèje aplinkoje, atlieka tas pačias funkcijas. Iki šiol žinomos 7 skirtingos povandeninès pilkujų ruonių (Halichoerus grypus) vokalizacijos, užfiksuotos jų poravimosi metu. Jūrinejje aplinkoje šios vokalizacijos dažnai maskuojamos (užgožiamos) antropogeniniu triukšmu, kurio apstu Lietuvos Respublikos Baltijos jūros teritorijoje. Viena pagrindinių ir dažniausiai pasitaikančių triukšmingų veiklų Lietuvos Respublikos Baltijos jūros dalyje - laivyba. Šiame straipsnyje pateikiami mokslinio tyrimo, kurio metu buvo ìvertintas Baltijos pilkųų ruonių vokalizacijų maskavimas laivybos povandeniniu triukšmu, rezultatai. Klaipėdos jūrų muziejuje buvo užfiksuotos 4 skirtingos Baltijos pilkujų ruonių vokalizacijų grupès, kurios palygintos su laivybos triukšmu, užfiksuotu Lietuvos Respublikos Baltijos jūros teritorijoje. Mokslinio tyrimo metu nustatyta, jog Baltijos pilkųjų ruonių vokalizacijos yra maskuojamos ruoniams esant net iki 5 kilometrų atstumu nuo praplaukiančių laivų, kurių dydis yra santykinai nedidelis. Lietuvos Respublikos Baltijos jūros teritorijoje, esant šiuolaikiniam laivybos srautui, ruonių vokalizacijų maskavimas, kaip manoma, yra dažnas reiškinys, turintis ekologinę reikšmę.

Raktiniai žodžiai: akustika, povandeninis triukšmas, pilkuju ruonių vokalizacijos, maskavimo potencialas.
\end{abstract}

